\title{
Taxonomy and systematics are key to biological information: Arabidopsis, Eutrema (Thellungiella), Noccaea and Schrenkiella (Brassicaceae) as examples
}

\author{
Marcus A. Koch ${ }^{1 *}$ and Dmitry A. German ${ }^{1,2}$ \\ ${ }^{1}$ Department of Biodiversity and Plant Systematics, Center for Organismal Studies Heidelberg, Heidelberg University, Heidelberg, Germany \\ 2 South-Siberian Botanical Garden, Altai State University, Barnaul, Russia
}

Edited by:

Cécile Nouet, University of Liège,

Belgium

\section{Reviewed by:}

Vincent Castric, CNRS - Université

Lille 1, France

Claire-Lise Meyer, Université Libre

de Bruxelles, Belgium

Herbert Hurka, University of

Osnabrück, Germany

\section{*Correspondence:}

Marcus A. Koch, Department of

Biodiversity and Plant Systematics, Center for Organismal Studies

Heidelberg, Heidelberg University,

Im Neuenheimer Feld 345,

D-69120 Heidelberg, Germany

e-mail:marcus.koch@

cos.uni-heidelberg.de

\begin{abstract}
Taxonomy and systematics provide the names and evolutionary framework for any biological study. Without these names there is no access to a biological context of the evolutionary processes which gave rise to a given taxon: close relatives and sister species (hybridization), more distantly related taxa (ancestral states), for example. This is not only true for the single species a research project is focusing on, but also for its relatives, which might be selected for comparative approaches and future research. Nevertheless, taxonomical and systematic knowledge is rarely fully explored and considered across biological disciplines. One would expect the situation to be more developed with model organisms such as Noccaea, Arabidopsis, Schrenkiella and Eutrema (Thellungiella). However, we show the reverse. Using Arabidopsis halleri and Noccaea caerulescens, two model species among metal accumulating taxa, we summarize and reflect past taxonomy and systematics of Arabidopsis and Noccaea and provide a modern synthesis of taxonomic, systematic and evolutionary perspectives. The same is presented for several species of Eutrema s. I. and Schrenkiella recently appeared as models for studying stress tolerance in plants and widely known under the name Thellungiella.
\end{abstract}

Keywords: Arabidopsis halleri, BrassiBase, Eutrema, knowledge database, Noccaea caerulescens, Schrenkiella, taxonomy, Thellungiella
Noccaea caerulescens (J. Presl and C. Presl) F. K. Mey. and Arabidopsis halleri (L.) O'Kane and Al-Shehbaz are the two top model-species among the Brassicaceae to study the ecology, physiology, molecular basis and evolution of metal stress and accumulation (e.g., Koch et al., 1998; Assunção et al., 2003; Clauss and Koch, 2006; Milner and Kochian, 2008; Krämer, 2010; Meyer and Verbruggen, 2012) (Figure 1). These species are indeed living in extreme environments, which is a phenomenon very often found in the Brassicaceae family. Another such group of species adapted to environments with high salt concentrations is known under the generic name Thellungiella O. E. Schulz. These "extremophytes" (Bressan et al., 2001; Inan et al., 2004; Amtmann, 2009) are widely used as a model for studying high salt resistance, drought and cold tolerance mechanisms in higher plant species.

All these taxa are, unfortunately, excellent examples to illustrate the lack of synergy across different biological disciplines (systematics/phylogeny on one hand and physiology, ecology, evolutionary biology, genetics and genomics, on the other). Information from these different disciplines is not crossreferenced; meaning systematic and taxonomic progress during the past decade(s) is being largely ignored. The enormous potential for comparative population and multiple-species based approaches is thus rarely fully explored. These species are discussed frequently within a misleading phylogenetic and evolutionary context and this applies to published data, which is still being cited without any (corrective) commentary.
In the following paragraphs we show that the taxonomic recognition of the genus Noccaea Moench and thereby Noccaea caerulescens is largely incorrect and frequently ignored by physiologists and molecular biologists. Instead "Thlaspi" is widely used. Moreover, we are referring here to four decades of research history (not limited to a few years). In contrast, biologists have been much more amenable to the use of any Arabidopsis (DC.) Heynh. taxon (terminology) during the same time period, presumably considering the genus as containing the "closest" relatives of the model plant Arabidopsis thaliana (L.) Heynh. (Clauss and Koch, 2006). Consequently, it was probably easier to educate scientists to work with particular "Arabidopsis" species, even if they are not closely related to the taxonomic "beacon" (Arabidopsis thaliana). Thellungiella represents another and probably the most acute of the discussed cases of a particular lack of interdisciplinary connections. Similar to Noccaea, a widely applied concept of Thellungiella in non-taxonomic literature generally ignores the state of the art of taxonomy and phylogeny of affected taxa. And in many cases systematics and taxonomy is wrongly used at species, generic, and tribal level with relevant consequences in the interpretation of the results. However, this incongruence has a much shorter history (though higher degree) than in Noccaea, and there is a chance to overcome this situation much faster. Our intention here is to present and discuss these issues in more detail and to illustrate the value of taxonomy and systematics as a bioinformatics tool (Koch et al., 2012). 




FIGURE 1 | Various representatives from the tribes Coluteocarpeae (Noccaea, Raparia, Coluteocarpus, Microthlaspi) and Camelineae (Arabidopsis)-photographs: M. A. Koch.

\section{TAXONOMIC HISTORY, BIOGEOGRAPHY AND SYSTEMATICS OF ARABIDOPSIS, NOCCAEA AND THELLUNGIELLA/EUTREMA \\ THE LIFE AND (HARD) TIMES OF THE GENUS NOCCAEA}

Various species belonging to the genus Noccaea have traditionally been treated under a broadly defined genus Thlaspi $\mathrm{L}$. This genus was originally described by Linnaeus (1753), and it should not be surprising that a 250 year-old generic concept, though undergoing various updates, does not reflect any real or meaningful phylogenetics. Much later, Meyer $(1973,1979)$ revised the generic concept based mostly on seed coat anatomy and embryology, and placed many of the former Thlaspi species into a well-defined genus Noccaea. As indicated by the authority Moench, Meyer was not the first who recognized this genus, but Moench did so in (1802) by recognition of the species, previously known as Iberis rotundifolia L. or Lepidium rotundifolium (L.) All. (and later widely accepted as Thlaspi rotundifolium (L.) Gaudin), as a single member of Noccaea thus making Noccaea rotundifolia the type of the genus, but also ignoring many other species to be integrated into Noccaea. Furthermore, Meyer did not only recognize the genus Noccaea, but he introduced also eleven additional new genera to newly combine various Thlaspi s. l. species into such genera as Raparia F. K. Mey., Microthlaspi F. K. Mey. and others.

It is remarkable that this taxonomic solution would have also combined most of the metal hyperaccumulator species of the former "Thlaspi" into one monophyletic group. However, Meyer's concept still assumes close relationships between different former "Thlaspi" segregates, which turned out later to be wrong. Molecular systematic studies (Mummenhoff and Koch, 1994; Mummenhoff et al., 1997a,b) in general confirmed Meyer's generic concept, but it was also demonstrated that some of the segregates are not closely related to each other. In particular, Thlaspi sensu Meyer (generic type T. arvense L.) is not at all related to Noccaea (Figure 2), and the two genera are placed in two different and not related tribes (Al-Shehbaz et al., 2006; Couvreur et al., 2010; Franzke et al., 2010).

Based on morphological and particularly anatomical characters, Meyer $(1973,1979)$ (correctly) recognized Noccaea as the well-defined group. Twenty years later, molecular evidence which confirmed this finding from a phylogenetic point of view was published (Mummenhoff and Koch, 1994; Zunk et al., 1996). But what happened subsequently, in the 10 years that followed? The new taxonomy was again neglected or overlooked by physiologists, ecologists and evolutionary biologists. Since Meyer started working on the genus Thlaspi sens. trad. in the early 1970s, he continuously published a series of monographs of all his new genera. A comprehensive volume focusing on Noccaea was presented by Meyer in (2006). Additional work has been presented confirming Noccaea as a distinct genus (Koch and Mummenhoff, 2001; Koch and Al-Shehbaz, 2004). However, most of the scientific contributions focusing on the model organism Noccaea caerulescens ignored these achievements and did not provide the relevant links (mentioned initially by Koch et al., 1993). There are various reasons that can explain this situation. One reason might be that almost all Meyer's works were published in German and in purely taxonomic journals. We tried to count the number of publications in the last 25 years indexed in the ISI Web of Science focusing on Noccaea/Thlaspi caerulescens any using one or the other taxonomic option (Figure 3; redrawn from Koch et al., 2012). The implication from this figure appears to be that more than three decades were required to disseminate according knowledge to a broader community which has only gradually moved toward using the combined wealth of information from taxonomy and wider disciplines (comparative biogeography, evolutionary history, trait and characters such as metal hyperaccumulation).

Since Noccaea comprises the vast majority of species diversity within Thlaspi sensu trad., which is well-known as a taxonomically complex entity, most of those problems are now connected with Noccaea. Neither generic limits, grouping within the genus, nor the limits and the relationships of a number of species have been finally resolved. The species richness estimates of Noccaea range considerably_from ca. 85 (Al-Shehbaz et al., 2006) to 120 (Al-Shehbaz, 2012). Phylogenetically, the best studied group is the North American Noccaea species complex (Koch and Al-Shehbaz, 2004), and only a limited group of a few European Noccaea species fall into well-supported clades (Koch et al., 1993; Mummenhoff and Koch, 1994).

Among the various Noccaea species well-known (and intensively studied) for their occurrence on metal rich habitats are European N. goesingensis (Halácsy) F. K. Mey., N. montana (L.) F. K. Mey., N. praecox (Wulfen) F. K. Mey., N. tymphaea (Hausskn.) F. K. Mey. (sometimes reported as Thlaspi pindicum Hausskn.) and N. sylvia (also known as Thlaspi alpinum subsp. 


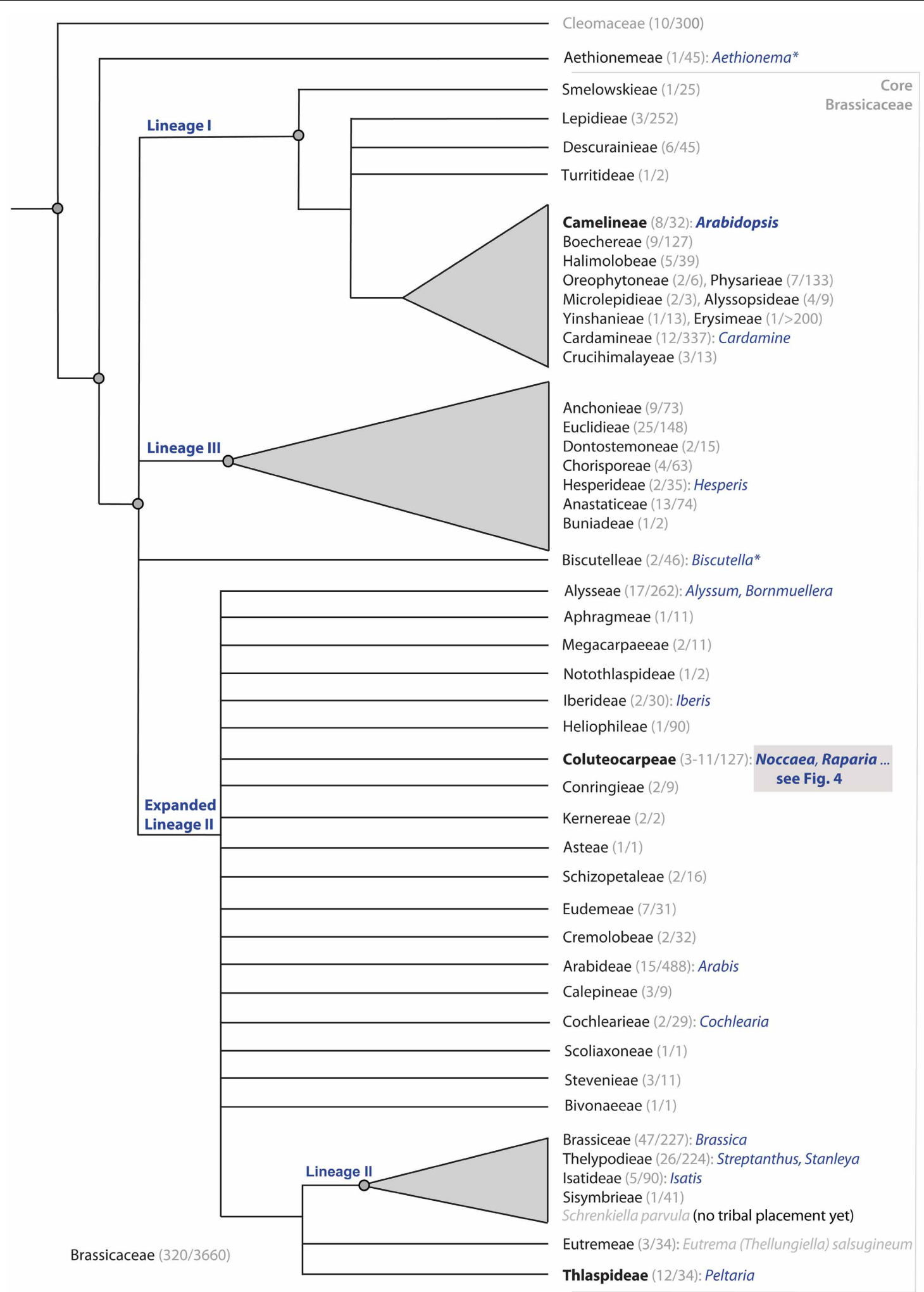

FIGURE 2 | Cartoon on phylogenetic relationships of the Brassicaceae among tribes, with given numbers of genera and species respectively (for detail, Koch et al., 2012). Tribes with species showing the trait of metal accumulation are indicated with some example genera named in blue (taken from Krämer, 2010; with several corrections of tribal affiliation). Tribes comprising the genus Arabidopsis (Camelineae), Noccaea and its relatives (Coluteocarpeae) and the few remaining Thlaspi species (Thlaspideae) are indicated in bold/black. Genera marked with an asterisk do also comprise species occurring frequently on metal rich soil types. 


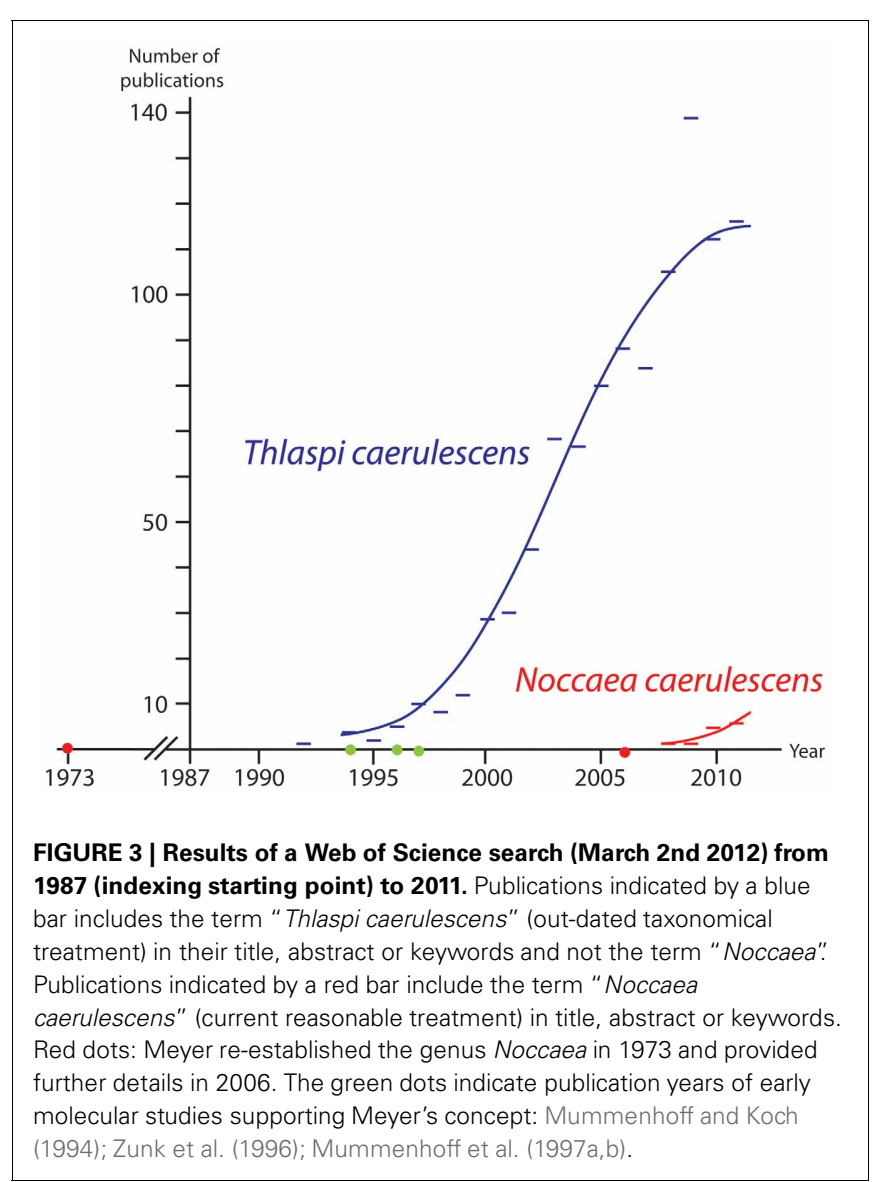

sylvium) (e.g., Vogel-Mikus et al., 2005; Taylor and Macnair, 2006) or North American N. fendleri (as Thlaspi montanum in Boyd and Martens, 1998) (for a most comprehensive review, see Reeves and Baker, 2000). Many other metallicolous species found with the generic designation Thlaspi/Noccaea are listed in Figure 4 and the best current reconstructed taxonomy is provided. In total 15 nickel accumulator and 32 zinc accumulator species have been described from the genus Noccaea and closely related genera [Masmenia F. K. Mey., Pseudosempervivum (Boiss.) Grossh.]. A few of them also accumulate cadmium and lead.

Noccaea caerulescens is among the most variable and taxonomically difficult species of the genus (see, for instance, Jalas et al., 1996, as Thlaspi caerulescens J. Presl and C. Presl). Its synonymy includes a number of species epithets (Meyer, 2006) and several (collectively up to seven only in the recent publications) subspecies are recognized by different authors(e.g., Clapham and Akeroyd, 1993; Jalas et al., 1996; Holub, 1998; Dvořáková, 2003; Meyer, 2006; Marhold, 2011). An additional complication is caused by differences in the attribution of the widely used illegitimate name Thlaspi alpestre L. (1763, non Jacq., 1762) which has long been and is still treated conspecific with either $N$. caerulescens (Cafferty and Jarvis, 2002) or closely related $N$. brachypetala (Jord.) F. K. Mey. (Meyer, 2006) which itself is treated by some authors as a subspecies of $N$. caerulescens [as $T$. caerulescens subsp. brachypetala (Jord.) O. Bolòs, Vigo, Masalles and Ninot] (e.g., Jalas et al., 1996), though the latter viewpoint is not generally followed. According to Meyer (2006), recent typification of the name T. alpestre L. (Marhold and Martonfi in Cafferty and Jarvis, 2002) finally brought it to synonymy of $N$. brachypetala which should have stopped taxonomic confusions connected with this Linnean binominal. However, it does not remove another problem further contributing to the complexity of nomenclature of this group, namely, persisting differences in the interfering concepts of $N$. caerulescens and $N$. brachypetala among taxonomists. Quite widely accepted, is a viewpoint separating the species morphologically primarily by petal length (1-1.5 mm long, equaling or up to 1,3 times exceeding sepals in $N$. brachypetala versus. 2-4 mm long and 1.5-3 times exceeding sepals in N. caerulescens) (e. g., Clapham and Akeroyd, 1993; Pujados Salvá, 1993, both as Thlaspi). This sufficiently differs from Meyer's approach "allowing” N. brachypetala to have petals $0.8-3 \mathrm{~mm}$ long. As a result, the limit between the two entities is not obvious, and a number of names of taxa described predominantly from central and eastern France are treated as synonyms of either $N$. caerulescens, or $N$. brachypetala (conf. Meyer, 2006 vs. Marhold, 2011), or as subspecies of any of them. Meyer $(1973,2006)$ accepted species status of N. brachypetala (with three subspecies) and, unlike other authors (e. g., Dvořáková, 2003) accepted only two subspecies of N. caerulescens: subsp. caerulescens and subsp. sylvestris (Jord.) F. K. Mey.; synonymy of the latter includes, in particular, T. calaminare (Lej.) Lej. and Courtois.

The above mentioned discrepancies along with the fact that Meyer's $(1973,1979,2006)$ circumscription of Noccaea, including the recognition of two subspecies of $N$. caerulescens and his generic concept has not been followed in recent floristic treatments in Europe, it is difficult to unravel putative distribution ranges and occurrence of the various taxa. For example, Meyer does not confirm previous reports of $N$. caerulescens for Spain (e.g., Clapham and Akeroyd, 1993; Pujados Salvá, 1993 as Thlaspi). Therefore, we provide a table showing the most important synonyms with their respective geographical source (Table 1) and based predominantly on Meyer's approach (Meyer, 2006). However, it should be noted here that we are missing substantial molecular, phylogeographic data linking taxonomy with evolutionary history in space and time. The few studies done so far can be summarized shortly. A study of limited resolution and using isoelectric focusing of the various subunits of the RuBisCO protein highlighted some closer relationships, especially between Noccaea caerulescens and N. brachypetala (Koch et al., 1993; nota: here also the old Thlaspi synonymy was used, but discussed within Meyer's framework). This closer affinity was later confirmed by DNA based markers (Mummenhoff and Koch, 1994). A more comprehensive study based on isozyme analysis and focusing on various populations of Noccaea caerulescens and N. brachypetala from contaminated and non-contaminated sites was presented later (Koch et al., 1998) demonstrating that the N. caerulescens ecotype accumulating metals might have evolved several times independently. There is also increasing ecological knowledge of the various populations of $N$. caerulescens, and it has been shown, for example, that there are significant differences in life-history traits (Macnair, 2007; Dechamps et al., 2011), in outcrossing rates (Koch et al., 1998; Duboix et al., 2003), or in the strength of 


\section{Coluteocarpeae (former Noccaeeae)}

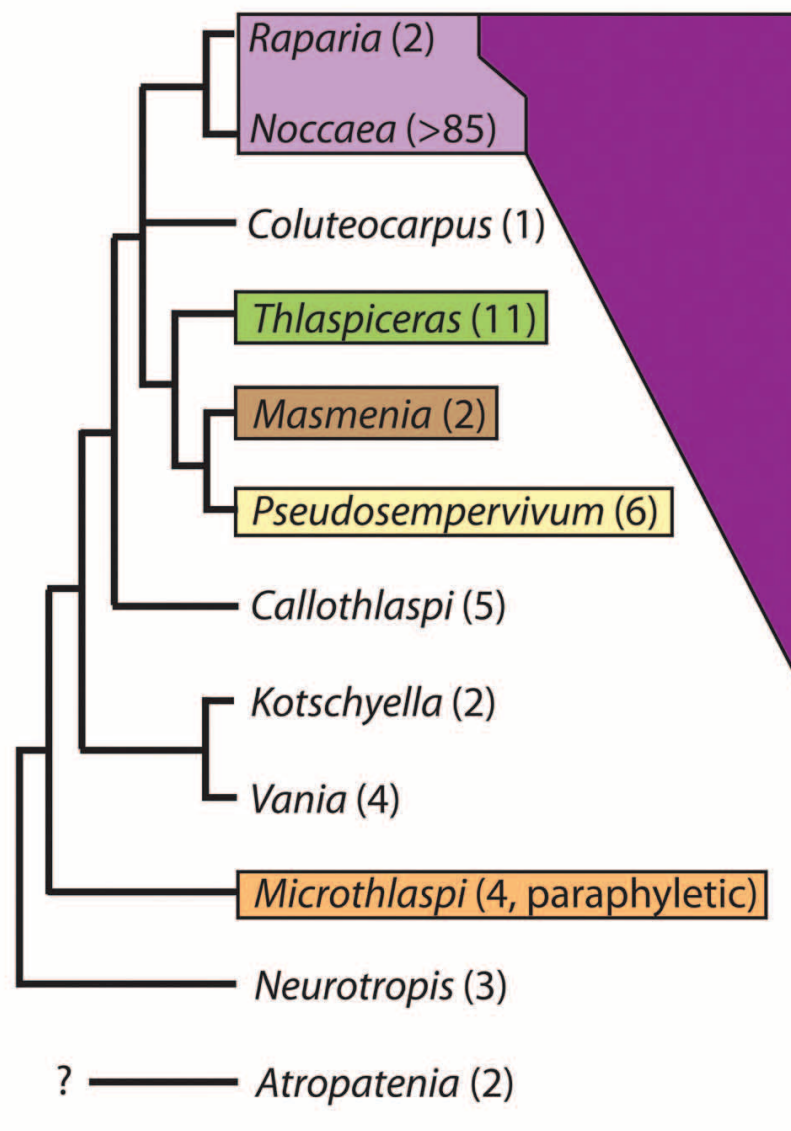

Raparia bulbosa

N. virens

N. graeca

N. brachypetala subsp. brachypetala

N. brachypetala subsp. tatrensis

N. goesingensis

N. epirota

N. ochroleuca

N. sylvia

N. corymbosa

N. cepaeifolia

N. tymphae

$\mathrm{N}$. aptera

N. boeotic

N. firmiensis

$\mathrm{N}$. caerulescens

N. annua

N. praecox

N. jankae

N. jankae
N. dacica

N. dacica
N. brevistyla

N. brevistyla subsp. rivalis

N. brevistyla subsp. pseudorivularis

N. salisii

N. nevadense

N. fendleri

N. limosellifolia

$\mathrm{N}$. limosellifo

$N$. lutescen

N. albanica
N. viridisepal

N. viridisepa
N. minima

N. kovatsi

N. occitanic

N. eburneosa

N. microphylla

$\mathrm{N}$. arenaria

Thlaspiceras oxyceras

T. elegans

T. eigeri

Masmenia rosularis

Pseudosempervivum aucheri

P. sempervivum

P. amanum

Microthlaspi perfoliatum

Ni, Zn, Cd, Pb

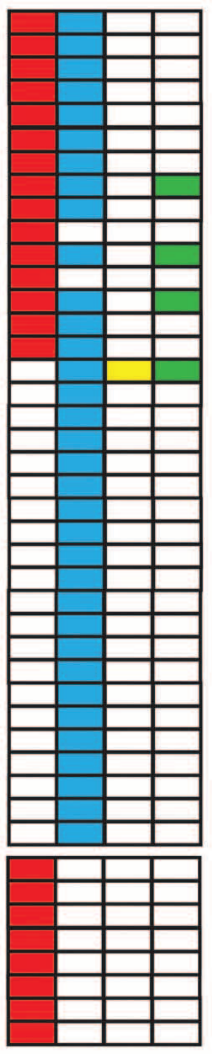

Thlaspi jaubertii

T. leblebicii

\section{Synonymy of metallicolous taxa of former Thlaspi and Cochlearia}

Cochlearia amana Contandr. \& Quézel = Pseudosempervivum amanum (Contandr. \& Quézel) Al-Shehbaz, Mutlu \& Dönmez Cochlearia aucheri Boiss. $=$ Pseudosempervivum aucheri (Boiss.) Pobed.

Noccaea boeotica F. K. Mess.

Noccaea camlikensis Aytac, Nordt \& Parolly

Noccaea eburneosa F. K. Mey.

Noccaea pseudorivularis (Hausskn. ex Bornm.) F. K. Mey. = Noccaea brevistyla subsp. pseudorivularis (Hausskn. ex Bornm.) F. K. Mey. Noccaea rivalis (C. Presl) F. K. Mey. = Noccaea brevistyla subsp. rivalis (C. Presl) F. K. Mey.

Thlaspi albanicum (F. K. Mey.) Greuter \& Burdet = Noccaea albanica F. K. Mey.

Thlaspi alpinum subsp. sylvium (Gaudin) P. Fourn. = Noccaea sylvia (Gaudin) F. K. Mey.

Thlaspi apterum Velen., = Noccaea aptera (Velen.. F. K. Mey.

Thlaspi avalanum Pancic ex Hayek = Noccaea aptera (Velen.) F. K. Mey

Thlaspi brachypetalum Jord, $=$ Noccaea brachypetala (Jord.) F. K. Mey.

Thlaspi bulbosum Spruner $=$ Raparia bulbosa $($ Spruner) F. K. Mey

Thlaspi brevistylum (DC.) Jord. = Noccaea brevistyla (DC.) Steud

Thlaspi caerulescens J. Presl \& C. Presl = Noccaea caerulescens (J.Presl \& C. Presl) F. K. Mey.

Thlaspi cariense Carlström $=$ Noccaea cariensis (Carlström) Parolly, Nordt \& Aytac

Thlaspi dacicum Heuff. $=$ Noccaea dacica (Heuff.) F. K. Mey.

Thlaspi eigii (Zohary) Greuter \& Burdet = Thlaspiceras eigii (Zohary) F. K. Mey.

Thlaspi eigii subsp. samuelssonii (F. K. Mey.) Greuter \& Burdet = Thlaspiceras eigii subsp. samuelssonii F. K. Mey

Thlaspi elegans Boiss. $=$ Thlaspiceras elegans (Boiss.) F. K. Mey.

Thlaspi epirotum Halácsy $=$ Noccaea epirota (Halácsy) F. K. Mey.
Thlaspi firmiense (F. K. Mey.) Greuter \& Burdet = Noccaea firmiensis F. K. Mey,

Thlaspi goesingense Halácsy = Noccaea goesingensis (Halácsy) F. K. Mey.

Thlaspi graecum Jord. $=$ Noccaea graeca (Jord.) F. K. Mey.
Thlaspi kerneri Huter = Noccaea minima (Ard.) F. K. Mey.

Thlaspi kovatsii Heuff. $=$ Noccaea kovatsii (Heuff.) F. K. Mey.

Thlaspi microphyllum Boiss. \& Orph. = Noccaea microphylla (Boiss. \& Orph.) F. K. Mey.

Thlaspi minimum Ard, = Noccaea minima (Ard.) F. K. Mey.

Thlaspi montanum auct. [from USA] = Noccaea fendleri $(A, G$ Gay) Holub

Thlaspi nevadense Boiss. \& Reut. = Noccaea nevadensis (Boiss. \& Reut.) F. K. Mey.

Thlaspi occitanicum Jord. $=$ Noccaea occitanica (Jord.) F. K. Mey.

Thlaspi ochroleucum Boiss. \& Heldr. = Noccaea ochroleuca (Boiss. \& Heldr.) F. K. Mey.

Thlaspi oxyceras (Boiss.) Hedge $=$ Thlaspiceras oxyceras (Boiss.) F. K. Mey.

Theppi pindicum Hauss

tymphaea (Hausskn.) F. K. Mey Thlaspi praecox Wulfen $=$ Noccaea praecox (Wulfen) F. K. Mey.

Thlaspi pseudorivulare Hausskn. ex Bornm.

Thlaspi rivale C. Presl $=$ Noccaea brevistyla subsp. rivalis (C. Pres) F. K. Mey.

Thlaspi rosulare Boiss. \& Ball = Masmenia rosularis ( Boiss. \& Balansa ) F.K.Mey.

Thlaspi rotundifolium subsp. cepaeifolium (Wulfen) Rouy \& Foucaud = Noccaea cepaeifolia (Wulfen) Rchb.

Thlaspi rotund follum subsp. corymbosum (J. Gay) Gremli = Noccaea corymbosa (J. Gay) F. K. Mey.

Thlaspi salisii Brügger = Noccaea salisii (Brüggo

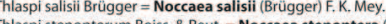

Thlaspi stenopterum Boiss. \& Reut. = Noccaea stenoptera (Boiss. \& Reut.) F. K. Mey.

Thlaspi sylvestre Jord. $=$ Noccaea caerulescens subsp. sylvestris (Jord.) F. K. Mey.

Thlaspi tatrense Zapal. = Noccaea brachypetala subsp. tatrensis (Zapal.) F. K. Mey.

Thlaspi tymphaeum Hausskn. = Noccaea tymphaea (Hausskn.) F. K. Mey-

Thlaspi virens Jord. $=$ Noccaea virens (Jord.) F. K. Mey.

Thlaspi viridisepalum (Podp.) Greuter \& Burdet $=$ Nocca viridisepala (Podp.) F. K. Mey
FIGURE 4 | Cartoon on phylogenetic relationships within the tribe Coluteocarpeae (syn. Noccaeeae) and the distribution of metallicolous taxa. This tribe comprises the majority of the many taxa previously combined under a broadly defined genus Thlaspi but also few former Cochlearia species. The phylogenetic hypothesis is based on DNA sequence data of the Internal Transcribed Spacers 1 and 2 of nuclear ribosomal DNA (Koch et al., 2012). Taxa have been considered as accumulators of nickel, cadmium, lead or zinc, respectively, if reports are available with the metal concentration in leafs exceeding thresholds as reviewed in Krämer (2010) (nickel and lead:
$1000 \mu \mathrm{g} / \mathrm{g}$ dry-mass; zinc: 10,000 $\mu \mathrm{g} / \mathrm{g}$ dry-mass; cadmium: $100 \mu \mathrm{g} / \mathrm{g}$ dry-mass). The compilation of taxa follows Brooks et al. (1977), Reeves (1988); Reeves and Brooks (1983); Reeves et al. (2001); Adigüzel and Reeves (2012), and see Reeves and Baker (2000) for a detailed review. Note: Correct name for this tribe is Coluteocarpeae (Dorofeyev, 2004) and not Noccaeeae (see Al-Shehbaz, 2012). For Atropatenia no ITS sequence data are actually available. Phylogenetic position and systematic affiliation of Thlaspi jaubertii Hedge and Thlaspi leblebicii Gemici and Görk are currently unclear. Total species number for the different genera is given in brackets. 
Table 1 | Noccaea caerulescens and $\boldsymbol{N}$. brachypetala synonymy and distribution including geographic source of respective type material.

\begin{tabular}{|c|c|c|c|}
\hline Name & Type locality & $\begin{array}{l}\text { Synonym of (following } \\
\text { Meyer, 2006) }\end{array}$ & $\begin{array}{l}\text { Distribution (following Meyer, } \\
\text { 2006) }\end{array}$ \\
\hline $\begin{array}{l}\text { Thlaspi caerulescens J. Presl and C. Presl } \\
\text { [T. alpestre subsp. sylvestre f. caerulescens } \\
\text { (J. Presl and C. Presl) Thell.; T. alpestre var. } \\
\text { caerulescens (J. Presl and C. Presl) Domin] }\end{array}$ & $\begin{array}{l}\text { Czech Republic } \\
\text { (Bohemia) }\end{array}$ & $\begin{array}{l}\text { Noccaea caerulescens } \\
\text { (J. Presl and C. Presl) F. K. } \\
\text { Mey. subsp. caerulescens }\end{array}$ & $\begin{array}{l}\text { Czech Republic, Poland, Germany, } \\
\text { Austria }\end{array}$ \\
\hline $\begin{array}{l}\text { T. sylvestre Jord. [T. alpestre subsp. } \\
\text { sylvestre (Jord.) Nyman; T. alpestre var. } \\
\text { sylvestre (Jord.) Bab.] }\end{array}$ & France (Lyon, Soucieux) & $\begin{array}{l}\text { Noccaea caerulescens } \\
\text { subsp. sylvestris (Jord.) F. K. } \\
\text { Mey }\end{array}$ & $\begin{array}{l}\text { Great Britain, Netherlands, Belgium, } \\
\text { France, Germany, Switzerland, Italy }\end{array}$ \\
\hline $\begin{array}{l}\text { T. alpestre var. calaminare Lej. } \\
\text { [T. calaminare (Lej.) Lej. and Courtois; } \\
\text { T. alpestre subsp. calaminare (Lej.) } \\
\text { O. Schwarz; T. caerulescens subsp. } \\
\text { calaminare (Lej.) Dvořáková; } N \text {. } \\
\text { caerulescens subsp. calaminaris (Lej.) } \\
\text { Holub] }\end{array}$ & Belgium (Wallonia) & & \\
\hline
\end{tabular}

T. alpestre var. glareosum Dumort., Belgium nomen nudum!

T. gaudinianum Jord. [T. alpestre subsp. gaudinianum (Jord.) Gremli; T. sylvestre

f. gaudinianum (Jord.) Rouy and Foucaud;

T. caerulescens subsp. gaudinianum (Jord.)

Dvořáková]

\begin{tabular}{ll}
\hline $\begin{array}{l}\text { T. vogesiacum Jord. [T. sylvestre var. } \\
\text { vogesiacum (Jord.) Rouy and Foucaud] }\end{array}$ & $\begin{array}{l}\text { France } \\
\text { (Vogeses, Bussang) }\end{array}$ \\
\hline $\begin{array}{l}\text { T. ambiguum Jord. [T. sylvestre var. } \\
\text { ambiguum (Jord.) Rouy and Foucaud] }\end{array}$ & $\begin{array}{l}\text { France } \\
\text { (Vogeses) }\end{array}$ \\
\hline T. alpestre var. porphyreum Wirtg. & Germany \\
\hline T. alpestre var. grandiflorum Godr. & France (Lorraine) \\
\hline T. sylvestre var. oligospermum Merino & NW Spain (Mellid)
\end{tabular}

[T. oligospermum (Merino) Greuter and

Burdet; N. oligosperma (Merino) Holub]

\begin{tabular}{|c|c|}
\hline $\begin{array}{l}\text { T. brachypetalum Jord. [T. alpestre var. } \\
\text { brachypetalum (Jord.) Gremli; T. alpestre } \\
\text { subsp. brachypetalum (Jord.) Thell.; T. } \\
\text { caerulescens subsp. brachypetalum (Jord.) } \\
\text { O. Bolòs, Vigo, Masalles and Ninot; } N \text {. } \\
\text { caerulescens subsp. brachypetala (Jord.) } \\
\text { Tzvel.] }\end{array}$ & $\begin{array}{l}\text { France (W Alps) } \\
\text { (Environs de Grenoble et } \\
\text { de Gap, bois de la } \\
\text { Grangette) }\end{array}$ \\
\hline T. alpestre L. (non Jacq.) & Austria \\
\hline T. virgatum Gren. and Godr. & $\begin{array}{l}\text { France (W Alps and E } \\
\text { Pyrenees) }\end{array}$ \\
\hline $\begin{array}{l}\text { T. lereschii Reut. [T. alpestre subsp. } \\
\text { lereschii (Reut.) Gremli; T. sy/vestre var. }\end{array}$ & $\begin{array}{l}\text { Vicinity to Lac Léman, } \\
\text { Jura mts. }\end{array}$ \\
\hline
\end{tabular}

W Alps (Jura mts.) occaea caerulescens subsp. sylvestris (Jord.) F. K. Mey

\section{ution (following Meyer} Czech Republic, Poland, Germany,

Austria

Adventive: Norway, Sweden,

Great Britain, Netherlands, Belgium, France, Germany, Switzerland, Italy

\section{Noccaea brachypetala} subsp. brachypetala (Jord.) F.K. Mey.
France, Spain, Switzerland, Italy, Austria

Adventive: Finland, Sweden 
Table 1 | Continued

\begin{tabular}{|c|c|c|c|}
\hline Name & Type locality & $\begin{array}{l}\text { Synonym of (following } \\
\text { Meyer, 2006) }\end{array}$ & $\begin{array}{l}\text { Distribution (following } \\
\text { Meyer, 2006) }\end{array}$ \\
\hline $\begin{array}{l}\text { T. vulcanorum Lamotte [T. brachypetalum var. } \\
\text { vulcanorum (Lamotte) Rouy and Foucaud] }\end{array}$ & Central France (Cantal) & & \\
\hline T. arnaudiae Jord. & Central France & & \\
\hline $\begin{array}{l}\text { T. suecicum Jord. [ T. alpestre subsp. } \\
\text { brachypetalum var. suecicum (Jord.) Hyl.] }\end{array}$ & Sweden & & \\
\hline $\begin{array}{l}\text { T. salticorum Jord. [T. brachypetalum var. } \\
\text { vulcanorum f. salticorum (Jord.) Rouy and } \\
\text { Foucaud] }\end{array}$ & France & & \\
\hline $\begin{array}{l}\text { T. verlotii Jord. [T. brachypetalum var. vulcanorum } \\
\text { f. verlotii (Jord.) Rouy and Foucaud] }\end{array}$ & France (W Alps, Isère) & & \\
\hline $\begin{array}{l}\text { T. nemoricolum Jord. [T. brachypetalum var. } \\
\text { nemoricolum (Jord.) Rouy and Foucaud] }\end{array}$ & France (Cantal) & & \\
\hline T. brachypetalum var. costei Rouy and Foucaud & France (Aveyron, Salles-Curan) & & \\
\hline $\begin{array}{l}\text { T. tatrense Zapał. [T. sylvestre subsp. tatrense } \\
\text { (Zapał.) Dvořáková; T. alpestre subsp. tatrense } \\
\text { (Zapał.) Soó; T. caerulescens subsp. } \\
\text { tatrense (Zapał.) Dvořáková] }\end{array}$ & Slovakia (Tatra mts., Krywañ) & $\begin{array}{l}\text { Noccaea brachypetala } \\
\text { subsp. tatrensis (Zapał.) F.K. } \\
\text { Mey. }\end{array}$ & $\begin{array}{l}\text { Czech Republic, Slovakia, } \\
\text { Austria }\end{array}$ \\
\hline T. alpestre var. stenopterum Borbás & South East Austria (Burgenland) & & \\
\hline T. alpestre var. demissorum Borbás & South East Austria (Burgenland) & & \\
\hline $\begin{array}{l}\text { T. huteri Pernh. [T. sylvestre var. huteri (Pernh.) } \\
\text { Dalla] }\end{array}$ & NE Italy (Gsies) & $\begin{array}{l}\text { Noccaea brachypetala } \\
\text { subsp. huteri (Pernh.) F. K. } \\
\text { Mey. }\end{array}$ & Austria, Italy \\
\hline
\end{tabular}

natural selection limiting gene flow between metalliferous and non-metalliferous locations (Besnard et al., 2009).

At present we have no direct evidence and calculations for the timing of Noccaea caeruelscens' split from a common ancestor. But considering the low genetic variation found within and between populations compared to other Brassicaceae genera and comparing it also with the evolutionary scenario of American Noccaea species (Koch and Al-Shehbaz, 2004) it can be concluded that $N$. caerulescens is of a Pleistocene origin and diverged from their European relatives less than one million years ago.

\section{WE LIST THE FOLLOWING CONCLUSIONS AND PROVIDE SUGGESTIONS FOR FUTURE RESEARCH}

(1) The name Noccaea caerulescens should be used instead of Thlaspi caerulescens in any contribution providing access to the correct systematic, evolutionary framework. This should prevent the accumulation of data interpreted in the wrong phylogenetic context.

(2) It is nearly impossible to find morphological characters that are clearly indicative of metallicolous ecotype(s) of $N$. caerulescens. Consequently, recognizing such plants as taxonomic entities of subspecies or species rank (e. g., subsp. calaminare) is not justified.
(3) Following Meyer's concept, all metallicolous populations together with non-metallicolous populations should be taxonomically treated as Noccaea caerulescens subsp. sylvestris with a western Central European distribution which include populations from the United Kingdom. The eastern Central European vicariant is best treated as $N$. caerulescens subsp. caerulescens, which also colonized Scandinavia very successfully. However, future phylogeographic studies will have to demonstrate if this concept can be followed (completed with genetic data). Regardless, we can assume a largely overlapping distribution area with extensive admixture since the last glacial maximum.

(4) It is not clear yet, how the different taxa of N. brachypetala (with the closest affinity) should be recognized. Among contrasting viewpoints, Meyer treats $N$. brachypetala as separate species with three subspecies mostly characterized by their occurrence at higher elevation from mountainous to alpine habitats (subsp. brachypetala, subsp. tatrensis (Zapał.) F. K. Mey., subsp. huteri (Pernh.) F. K. Mey.). When considering populations from France (e.g., Massif Central) or Spain, however, this concept might need to be revised.

(5) It has also to be noted that few other taxa from Meyer's series Alpestres show very close affinities (geographically and taxonomically) with $N$. caerulescens and $N$. brachypetala: 
namely Noccaea virens (Jord.) F. K. Mey. (often treated also as a subspecies of $N$. caerulescens) and $N$. salisii (Brügger) F.K. Mey. In addition maybe also N. occitanica (Jord.) F.K. Mey. and its two subspecies from Meyer's series Occitanicae are within the $N$. caerulescens/N. brachypetala species aggregate.

\section{LIFE IN THE FAST LANE: THE GENUS ARABIDOPSIS}

"Arabidopsis and its poorly known relatives", this title was used recently for a review introducing the closest relatives of Arabidopsis thaliana, and all members of the currently defined genus Arabidopsis (Clauss and Koch, 2006). A major part of the taxonomic confusion arose after the year 1872 when many species were transferred into a genus Arabidopsis based on a few simple morphological characters (cf. latiseptate siliques and branched trichomes). As a result, some 60 species were recognized in Arabidopsis in a traditional sense (see Al-Shehbaz et al., 1999; German and Ebel, 2005). Major aspects of this Arabidopsis' taxonomical history were compiled in detail Al-Shehbaz et al. (1999); Al-Shehbaz and O'Kane (2002) and nine Arabidopsis species with several subspecies were recognized by this time. Note that Hedge (1968) indirectly suggested a closer relationship between Arabidopsis and Arabis L. He indicated that the two genera differ only in the position of the cotyledons relative to the radicle in the seeds and that the Himalayan species Arabidopsis wallichii (Hook. f. and Thomson) N. Busch is essentially intermediate between the two genera. However, as molecular data were lacking, Hedge and others were not aware that, in fact, the genus Arabis at that time comprised several unrelated evolutionary lineages (see Koch et al., 1999, 2000, 2001; Karl and Koch, 2013). In addition, the historical concept of Arabis as a genus does not exist anymore (Koch et al., 1999, 2001; Karl and Koch, 2013). Because taxa from both genera, Arabidopsis and Arabis, share a taxonomic history, they frequently exhibit related taxonomic nomenclatural problems with numerous misleading phylogenetic implications. See also the taxon Arabidopsis wallichii, which Hedge suggested to be an intermediary between Arabidopsis and Arabis, and which has now been christened Crucihimalaya wallichii (Hook. f. and Thomson) Al-Shehbaz, O'Kane and R. A. Price and is not closer related to any of these genera phylogenetically.

The new and currently accepted concept of the genus Arabidopsis was presented 10-15 years ago (O'Kane and AlShehbaz, 1997, 2003), in parallel by a contribution from Koch et al. (1999) who unraveled some taxonomical problems including both Arabis and Arabidopsis. Some species and subspecies were added later, however, either because of a transfer of taxa previously never associated with Arabidopsis (Warwick et al., 2006), or a description of a new species (Kadota, 2007), Mostly, the delay was due to raising the rank of some other taxa treated by O'Kane and Al-Shehbaz (l. c.) as subspecies or synonyms (Dorofeyev, 2002; Marhold et al., 2003; Shimizu et al., 2005; Kolník and Marhold, 2006; Iljinska et al., 2007; Kadota, 2007; Elven and Murray, 2008). In summary, in many cases it reflected the delimitations of previous authors. As a result, depending on the approach, Arabidopsis can be estimated as a genus comprising at least nine species and six subspecies (O'Kane and Al-Shehbaz,
1997), up to 13 species and nine subspecies (e.g., summarized in Koch et al., 2008).

It is not only A. halleri that grows on metal rich soils, but initial work has been also done on North American A. lyrata (L.) O'Kane and Al-Shehbaz from serpentine soils (Turner et al., 2008, 2010). And also in Eastern Austria some populations of A. lyrata are geographically close to serpentine outcrops (Schmickl and Koch, 2011).

Delimitation of Arabidopsis halleri is not congruent among taxonomists. Up to five subspecies can be recognized (O'Kane and Al-Shehbaz, 1997, 2003; Kolník and Marhold, 2006; Koch et al., 2008) though two of them, A. halleri subsp. gemmifera (Matsum.) O'Kane and Al-Shehbaz and A. halleri subsp. ovirensis (Wulfen) O'Kane and Al-Shehbaz are accepted by some authors as separate species, A. gemmifera (Matsum.) Kadota and A. ovirensis (Wulfen) A. P. Iljinsk., respectively (Kadota, 2007; Iljinska et al., 2007). Taxonomic treatment of Kolník and Marhold (2006) recognizes three predominantly Central European subspecies: most common subsp. halleri (latitudinally from Poland to Italy and Serbia and longitudinally from Belgium and France to W Ukraine and Moldova; substrate-indifferent, ranging from foothills to alpine belt), subsp. tatrica (Pawł.) Kolník (W Carpathian endemic, almost completely confined to Slovakia; substrate-indifferent, ranging from foothills to alpine belt), and subsp. dacica (Heuff.) Kolník (E and S Carpathians [Romania], probably somewhat further southwards into the Balkans; restricted to acid substrata and predominantly alpine, rarely montane habitats). And, indeed, E Asian A. halleri subsp. gemmifera is not only genetically separated from the other subspecies (Koch et al., 2008), but also geographically fully isolated. Arabidopsis halleri subsp. ovirensis has been originally described as endemic to the East Austrian high mountain range at Mount Obir, in Carinthia. Reports from other localities (e.g., from Romania and Ukraine) need confirmation. Genetic results showing some unique genetic markers in these respective populations are in agreement with this endemic distribution (Koch and Matschinger, 2007; Koch et al., 2008).

In the case of Arabidopsis halleri we have some more detailed evidence for its evolutionary history. It has been shown that all five above mentioned subspecies are closely related to each other, and that one major center of genetic diversity is located in the Eastern Austrian Alps (Koch and Matschinger, 2007). Very similar to N. caerulescens (Koch et al., 1998), it has also been concluded for A. halleri that metallicolous populations have been founded separately from distinct non-metallicolous populations without suffering founding events (Pauwels et al., 2005). This study was exclusively focused on $A$. halleri, and did not mention any further subspecies. However, it is likely that the authors included one sample of $A$. halleri subsp. tatrica with a distinct chloroplast haplotype not found in the remaining Central European populations. A comprehensive phylogeographic scenario was presented recently (Pauwels et al., 2012), and although the accessions studied were again not characterized taxonomically, many helpful comments linking taxonomy with genetic evidences were provided. High levels of genetic diversity found in the eastern region of the European Alps and initially demonstrated by Koch and 
Matschinger (2007) were confirmed and explained convincingly by admixture and secondary contact of different European gene pools.

With similar parallels to Noccaea caerulescens, the evolutionary scenario of $A$. halleri is best placed among Pleistocene glaciation and deglaciation cycles (Koch and Matschinger, 2007). In a more detailed study, Roux et al. (2011) suggested the onset of radiation within A. halleri to be 335,000 [272,800-438,200] years ago, but because this study lacks other subspecies, a deeper evolutionary split is possible.

In contrast to Noccaea caerulescens, and bearing in mind the detailed investigations in Arabidospis species (e.g., A. thaliana and A. lyrata), the number of genetic-evolutionary studies focusing on Arabidopsis halleri is high (e.g., Van Rossum et al., 2004; Meyer et al., 2009; Heidel et al., 2010). Numerous ecological studies are of course also available focusing on herbivory (Kawagoe and Kudoh, 2010), flowering time (Shimizu et al., 2011) or reproduction (Llaurens et al., 2008), for example.

\section{AS WITH NOCCAEA CAERULESCENS, WE PROVIDE SOME CONCLUSIONS AND RECOMMENDATIONS}

(1) Within A. halleri there are three to five different subspecies (gemmifera, tatrica, halleri, ovirensis, and dacica), of which A. halleri subsp. ovirensis is a genetically distinct endemic taxon. Thus, A. halleri subsp. ovirensis and geographically isolated A. halleri subsp. gemmifera could be treated as species, but it would be difficult to present convincing morphological evidence to recognize them accordingly, which should be a pre-requisite prior to any further taxonomical changes.

(2) The metal accumulating and metallicolous populations characterized so far are mostly from A. halleri subsp. halleri. However, zinc and cadmium accumulating populations have been characterized also within A. halleri subsp. gemmifera (Kubota and Takenaka, 2003; Kashem et al., 2007) and occurrence of subsp. tatrica on metal-contaminated soils has been reported (Kolník and Marhold, 2006).

\section{THELLUNGIELLA: AN EMERGING MODEL SYSTEM WHICH REMAINS TAXONOMICALLY CHALLENGING}

Thellungiella O.E. Schulz is gradually becoming established as a new (Arabidopsis-like) extremophyte model ideal for studying salt, drought and cold tolerance (beginning some 12 years ago, Bressan et al., 2001). During this period, it has become an established model system (see thellungiella.org) and complete genomes of two Thellungiella species, T. salsuginea (Pall.) O.E. Schulz and T. parvula (Schrenk) Al-Shehbaz and O'Kane, are now available (Dassanayake et al., 2011; Wu et al., 2012) providing a resource for deep insights into the evolutionary mechanisms underlying stress tolerance and various other physiological processes.

Since the advent of these genomic resources, a considerable amount of "simple" but basic information regarding Thellungiella taxonomical diversity, phylogeny and geographical range has accumulated which has been (and still is) heavily neglected. As a result, the current concept of Thellungiella in these studies implies polyphyly and a mixture of up to three species. This has serious negative consequences: a source of rapidly proliferating misinterpretations and even artifacts (when the functions of one biological species are attributed to another).

In 2001, when the review of Bressan et al. (2001) was published, Thellungiella was treated as a genus of three species, $T$. salsuginea, T. parvula and T. halophila (C. A. Mey.) O.E. Schulz (Zhou et al., 2001) and their phylogenetic position and relationships were rather unclear. As evidenced from studies of stress tolerance, the name $T$. halophila was applied wrongly (right from the start). This is perfectly illustrated by the following sentence: "Thellungiella halophila, previously classified as Arabidopsis halophila, recently has been reclassified as Thellungiella salsuginea (Al-Shehbaz et al., 1999), which now can be considered synonymous with Thellungiella halophila (salt cress)" (Inan et al., 2004). In fact, the latter species is not mentioned in Al-Shehbaz et al. (1999), and this obvious confusion most likely has its roots in an over-interpretation of the earlier data of Al-Shehbaz and O'Kane (1995) who suspected possible (but did not absolutely claim) conspecificity of T. halophila with T. salsuginea. These authors did not make a formal synonymization of $T$. halophila and recognized Thellungiella as a "genus of two (or perhaps three [i. e., T. halophila, T. parvula and T. salsuginea]) species" thus keeping the question open till the study of the type material of T. halophila. Later, distinctness of the two discussed species was confirmed (Zhou et al., 2001), but the practice of using the name T. halophila instead of T. salsuginea in non-taxonomic literature was cast. Note that if the taxa were conspecific, the name T. salsuginea should have been applied for the united species as having priority over $T$. halophila and, second, the binominal "Arabidopsis halophila" has never been validly published, i.e., it can not be used as a scientific name.

Subsequently, one more closely related species, T. botschantzevii D. German, was discovered (German, 2002). The phylogenetic position and relationships of Thellungiella was first preliminarily revealed by O'Kane and Al-Shehbaz (2003) who found it closely allied with one member of Eutrema R. Br. s. str. and non-monophyletic, if $T$. parvula was included. The item was further elucidated by Warwick et al. (2006) who showed that Thellungiella s. str. (without T. parvula which was not studied in that work) is monophyletic but is nested within the paraphyletic Eutrema. Based on those results, Thellungiella was recognized as a congeneric with Eutrema, and the latter genus was expanded to accommodate, in particular, all (four) Thellungiella representatives, including T. parvula [named as E. botschantzevii (D. German) Al-Shehbaz and Warwick, E. halophilum (C. A. Mey.) Al-Shehbaz and Warwick, E. parvulum (Schrenk) Al-Shehbaz and Warwick, and E. salsugineum (Pall.) Al-Shehbaz and Warwick] (Al-Shehbaz and Warwick, 2005).

The position of T. parvula was then tested in the context of a family-wide phylogeny (German et al., 2009) and its distinct position outside not only Eutrema but also the tribe Eutremeae Al-Shehbaz, Beilstein and E.A. Kellogg was demonstrated. This finding along with the re-evaluation of the species' morphology, resulted in recognition of a new genus, Schrenkiella D. German and Al-Shehbaz, with a single species, thereafter $S$. parvula (Schrenk) D. German and Al-Shehbaz (German and Al-Shehbaz, 2010). Currently Schrenkiella is among 20 (out of 321) genera of Brassicaceae who's precise phylogenetic position and tribal 
affiliation still remains uncertain (Al-Shehbaz, 2012) though its placement within the "core evolutionary lineage II" (Figure 2) which includes, in particular, Brassica L., is obvious (some results reveal its closer affinity with the tribe Thelypodieae Prantl-R. Schmickl, pers. comm.; see also Cheng et al., 2013).

In parallel to the above taxonomic and phylogenetic clarifications, the data on distribution of three "core" Thellungiella species and $S$. parvula were also considerably updated. Thus, $T$. botschantzevii, initially described as endemic to the south-west Siberia, was found in Kazakhstan (German, 2006) and subsequently in Europe (German, 2008). Moreover, it turned out that all previous reports of $T$. salsuginea from Europe belong to $T$. botschantzevii (German, 2008) and distribution of T. salsuginea is confined to Asia and North America. Finally, occurrence of both T. halophila and S. parvula in China was not confirmed where the single Thellungiella species, T. salsuginea, is documented by herbarium vouchers to date (German and Chen, 2009). Notably, among the discussed species, the most widely mentioned $T$. halophila possesses the narrowest distribution area being restricted to Kazakhstan where other three species do also occur.

Misapplication of various data in relation to Thellungiella is thus comparatively wide and extensive. There was some hope that this situation would turn round after the publication of Amtmann (2009) where some of the above discrepancies were briefly highlighted and, indeed, some improvement can be observed in a gradual switching from the name $T$. halophila to $T$. salsuginea (e. g., Lugan et al., 2010; Oh et al., 2010; Orsini et al., 2010; Wu et al., 2012) or E. salsugineum (Yang et al., 2013). However, misnomers persist: T. salsuginea named as T. halophila (e.g., Guo et al., 2012; Lamdan et al., 2012). Moreover, even in those papers where the species name T. salsuginea (or E. salsugineum) is correctly applied for what is indeed this species, T. halophila is often treated now as its synonym (e.g., Oh et al., 2010; Orsini et al., 2010; Pang et al., 2012; Yang et al., 2013), which, as shown above, is completely wrong, and use of the characteristics like "Thellungiella halophila/salsuginea" (Ghars et al., 2012) or "Thellungiella halophila (Salt cress also known as Eutrema salsugineum)" (Thellungiella halophila Genome Project, 2011) is equally inappropriate. Therefore, the misunderstanding is continuing, and it is still a very rare case when all three species of true Thellungiella are clearly distinguished and their physiological traits are characterized separately (Lee et al., 2012) and real differences in mechanisms of response to the stress factors at the species level are demonstrated (De Boer et al., 2007). This is the only adequate approach to be established in the experimental studies of Thellungiella, and brief comparative characteristics of its three closely related species showing some of their morphological characters along with geographic distribution are summarized in Table 2; the data on mating system (self-compatibility versus incompatibility) emphasizing the difference between $T$. halophila and $T$. salsuginea are also included.

Regarding the genus Thellungiella itself (lectotype species T. salsuginea), as mentioned before, currently available phylogenetic information indicates its placement within Eutrema. Therefore, using the generic name Thellungiella implies paraphyletic concept of Eutrema. Taking this into consideration, the use of the latter generic name instead of Thellungiella is preferable. However, Thellungiella clade (within Eutrema) is monophyletic with highest support in all relevant studies ( $O$ 'Kane and Al-Shehbaz, 2003; Warwick et al., 2006; Schmickl, pers. comm.). Consequently, use of the name Thellungiella for T. salsuginea and two closely related species (not for $S$. parvula) would not severely affect the evolutionary context of relevant studies as soon as it would be applied to the monophyletic group within Eutremeae. This is not the case of morphologically and, more important, phylogenetically more distant $S$. parvula.

It should be mentioned that rather recently an attempt to expand Thellungiella with another two species, namely T. pumila (Steph.) V.I. Dorof. and T. toxophylla (M. Bieb.) V.I. Dorof., has been undertaken (Dorofeyev, 2002). Although in the second case this decision has some morphological justification, this is apparently a matter of homoplasy evolved under similar conditions (the species is also halophytic) and the above viewpoint did not get support from any phylogenetic study. Relevant species are currently accepted as Olimarabidopsis pumila (Steph.) Al-Shehbaz, O'Kane and Price and Pseudoarabidopsis toxophylla (M. Bieb.) Al-Shehbaz, O'Kane and Price from the tribes Alyssopsideae Al-Shehbaz, Warwick, Mummenhoff and M. Koch and Camelineae DC., respectively (Al-Shehbaz, 2012), both unrelated to Eutremeae.

\section{CONCLUSIONS AND SUGGESTIONS ON FUTURE THELLUNGIELLA RESEARCH}

(1) Generic name Thellungiella is currently being applied in genomic and physiological literature to up to four species.

(2) Three of these four species (T. botschantzevii, T. halophila, T. salsuginea) represent true Thellungiella which is monophyletic but is phylogenetically within Eutrema (tribe Eurtemeae). In order to avoid paraphyletic concept of Eutrema, the use of this generic name instead of Thellungiella is preferable though using the latter name does not really distort the evolutionary context of the results of relevant studies.

(3) All three representatives of true Thellungiella are closely related but distinct species which is well supported by their morphology and distribution. Hence, mixing them up (which is especially case for T. halophila and T. salsuginea) is inappropriate as it would result in producing artifacts. In particular, the name T. halophila can not be treated as either the former name or a synonym of $T$. salsuginea. Instead, in all cases of such misapplication it is necessary to clarify which species was in fact studied and specify which name to which species was misapplied (most often the name T. halophila was misused for the plants of T. salsuginea). Whenever possible, geographic origin of the seed material should be specified as in many cases it can help to verify/confirm identification.

(4) Unlike the above species, T. parvula can not be treated as a member of either Thellungiella or Eutrema and represents monospecific genus Schrenkiella not very closely related to Eutremeae; its phylogenetic position needs further elucidation. For this reason, using the name T. parvula as well as E. parvulum implies wrong phylogenetic and evolutionary context and should be avoided. 
Table 2 | Brief comparative morphological, geographic and biological characteristics of Thellungiella s. str. species.

\begin{tabular}{|c|c|c|c|}
\hline Taxon/character & T. salsuginea & T. botschantzevii & T. halophila \\
\hline Stem leaves & Entire, base deeply cordate & Entire, base cordate-sagittate & $\begin{array}{l}\text { Entire to pinnate, base } \\
\text { cordate to subamplexicaul }\end{array}$ \\
\hline Indumentum & Absent & $\begin{array}{l}\text { Present (sparse simple trichomes, } \\
\text { mostly on lower leaves) }\end{array}$ & Absent \\
\hline $\begin{array}{l}\text { Seed number } \\
\text { per fruit }\end{array}$ & (56)60-100 & $30-40(44)$ & $16-32$ \\
\hline Petals (mm) & $2.5-3.7 \times 1.0-1.7$ & $2.0-2.5 \times 1.0-1.1$ & $2.5-3.5 \times 1.5-1.9$ \\
\hline Self-compatibility & Compatible* & Compatible* & Incompatible* \\
\hline
\end{tabular}

${ }^{*}$ Bert de Boer, pers. comm.

\section{CONCLUSIONS}

Biological research is driven by comparative approaches across disciplines (in the widest sense). The choice of Arabidopsis thaliana as the first model organism of flowering plants created the first fixed point of reference. Sequencing of its genome a decade ago (The Arabidopsis Genome Initiative 2002), has facilitated genomic comparisons in plants: for annotated genes, structural rearrangements and latterly SNP frequencies among multiple Arabidopsis accessions (1001 Genome Project). Since the advent of this reference genome, many other organisms have become well-established as model systems, allowing in-depth comparative analyses, rice from the monocots within flowering plants for example (Goff et al., 2002; Yu et al., 2002). Prior to the advent of molecular biology in evolutionary research, broadly relevant studies within the Brassicaceae family mainly focused on the characterization and breeding of agronomically important species such as cabbage or rapeseed. The same is true for crucifer systematics and taxonomy (Koch et al., 2003; Koch and Al-Shehbaz, 2009). Taxonomy and systematics predating the advent of molecular marker systems accumulated relatively isolated information whose conclusions were neither taxonomically nor evolutionarily comprehensive.

This gap of comprehensive knowledge created a source of substantial problems for researchers because systematics and

\section{REFERENCES}

Adigüzel, N., and Reeves, R. D. (2012). Important serpentine areas of Turkey and distribution patterns of serpentine endemics and nickel accumulators. Bocconea 24, 7-17.

Al-Shehbaz, I. A. (2012). A generic and tribal synopsis of the Brassicaceae. Taxon 61, 931-954.
Al-Shehbaz, I. A., Beilstein, M. A., and Kellogg, E. A. (2006). Systematics and phylogeny of the Brassicaceae (Cruciferae): an overview. Plant Syst. Evol. 259, 89-120. doi: 10.1007/s00606-0060415-z

Al-Shehbaz, I. A., and O'Kane, S. L. Jr. (1995). Placement of Arabidopsis parvula in Thellungiella

taxonomy knowledge is the "access key" to biological information needed for any kind of comparative research. This has been outlined in detail and precisely phrased by Paterson and colleagues' headline (Paterson et al., 2010): "Names are key to the big new biology". Meanwhile there is no doubt that taxonomic databases do play a central role in providing adequate biological information (e.g., The Plant List, 2010). Such an online information and knowledge tool, BrassiBase, (http://brassibase.cos. uni-heidelberg.de/) has been launched recently for Brassicaceae (Koch et al., 2012) with the intention that this bioinformatics tool can be used for the integration of taxonomy, systematics and the evolutionary biology that underpins phylogenetics.

\section{ACKNOWLEDGMENTS}

This work was supported by a grant from the German Research Foundation (Deutsche Forschungsgemeinschaft, DFG) KO2302$13 / 1$ within the framework of the priority research programme "Adaptomics" (DFG-SSP 1529) to Marcus A. Koch and providing resources to develop the BrassiBase database system. We are very grateful to Graham Muir for many excellent comments and suggestions and Roswitha Schmickl for compiling sequence data from BrassiBase, and Bert de Boer for sharing the unpublished data on peculiarities of mating system in Thellungiella s. str. species.

(Brassicaceae). Novon 5, 309-310. doi: 10.2307/3391953

Al-Shehbaz, I. A., and O'Kane, S. L. Jr. (2002). "Taxonomy and phylogeny of Arabidopsis (Brassicaceae)", in The Arabidopsis Book, eds C. R. Somerville and E. M. Meyerowitz (Rockville, MA: American Society of Plant Biologists), 22. doi: 10.1199/tab.0001
Al-Shehbaz, I. A., O'Kane, S. L. Jr., and Price, R. A. (1999). Generic placement of species excluded from Arabidopsis. Novon 9, 296-307. doi: 10.2307/3391724

Al-Shehbaz, I. A., and Warwick, S. I. (2005). A synopsis of Eutrema (Brassicaceae). Harvard Pap. Bot. 10, 129-135. doi: 10.3100/10434534(2005)10[129:ASOEB]2.0.CO;2 
Amtmann, A. (2009). Learning from evolution: Thellungiella generates new knowledge on essential and critical components of abiotic stress tolerance in plants. Mol. Plant 2, 3-12. doi: 10.1093/mp/ssn094

Assunção, A. G. L., Schat, H., and Aarts, M. G. M. (2003). Thlaspi caerulescens, an attractive model species to study heavy metal hyperaccumulation in plants. New Phytol. 159, 351-360. doi: 10.1046/j.14698137.2003.00820.x

Besnard, G., Basic, N., Chrsitin, P.-A., Savova-Bianchi, D., and Galland, N. (2009). Thlaspi caerulescens (Brassicaceae) population genetics in western Switzerland: is the genetic structure affected by natural variation of soil heavy metal concentrations? New Phytol. 181, 974-984. doi: 10.1111/j.1469-8137.2008.02706.x

Boyd, R. S., and Martens, S. N. (1998). Nickel hyperaccumulation by Thlaspi montanum var. montanum (Brassicaceae): a constitutive trait. Am. J. Bot. 85, 259-265. doi: $10.2307 / 2446314$

Bressan, R. A., Zhang, C., Zhang, H., Hasegawa, P. M., Bohnert, H. J., and Zhu, J. K. (2001). Learning from the Arabidopsis experience: the next gene search paradigm. Plant Physiol. 127, 1354-1360. doi: 10.1104/pp.010752

Brooks, R. R., Lee, J., Reeves, R. D., and Jaffré, T. (1977). Detection of nickeliferous rocks by analysis of herbarium species of indicator plants. J. Geochem. Explor. 7, 49-57.

Cafferty, S., and Jarvis, C. E. (2002). Typification of Linnean plant names in Brassicaceae (Cruciferae). Taxon 51, 529-537. doi: 10.2307/1554869

Cheng, F., Mandáková, T., Wu, J., Xie, Q., Lysak, M. A., and Wang, X. (2013). Dicephering the diploid ancestral genome of the mesohexaploid Brassica rapa. Plant Cell 25, 1541-1554. doi: 10.1105/tpc. 113.110486

Clapham, A. R., and Akeroyd, J. R. (1993). "Thlaspi L," in Flora Europaea, Vol. 1, 2 Edn. eds T. G. Tutin, N. A. Burdes, A. O. Chater, J. R. Edmondson, V. H. Heywood, D. Moore et al. (Edingburgh: Cambridge University Press), 384-388.

Clauss, M., and Koch, M. A. (2006). Arabidopsis and its poorly known relatives. Trends Plant Sci. 11, 449-459. doi: 10.1016/j.tplants.2006.07.005

Couvreur, T. L. P., Franzke, A., ALShehbaz, I. A., Bakker, F. T., Koch, M. A., and Mummenhoff, K.
(2010). Molecular phylogenetics, temporal diversification and principles of evolution in the mustard family (Brassicaceae). Mol. Biol. Evol. 27, 55-71. doi: 10.1093/molbev/msp202

Dassanayake, M., Oh., D.-H., Haas, J. S., Hernandez, A., Hong, H., Ali, S., et al. (2011). The genome of the extremophile crucifer Thellungiella parvula. Nat. Genet. 43, 913-920. doi: 10.1038/ng.889

De Boer, A., Hardiyanta, S., Almeida P. F., da Costa Pereira, D., Iachina, K., Verheijen. L., et al. (2007). "Expression of $\mathrm{Na}+$ and $\mathrm{K}+$ transporters in different Thellungiella ecotypes," in XIV International Workshop in Plant Membrane Biology. Valencia, Spain, June 26-30, 2007. Abstracts. P10-25. P. 217.

Dechamps, C., Elvinger, N., Meerts, P., Lefèbvre, C., Escarré, J., Colling, G., and Noret, N. (2011). Life history traits of the pseudometallophyte Thlaspi caerulescens in natural populations from Northern Europe. Plant Biol. 13, 125-135. doi: 10.1111/j.1438-8677.2010.00387.x

Dorofeyev, V. I. (2002). Cruciferae of European Russia. Turczaninowia 5, 3, 5-114 (in Russian).

Dorofeyev, V. I. (2004). System of family Cruciferae B. Juss. (Brassicaceae Burnett). Turczaninowia 7, 3, 43-52 (in Russian).

Duboix, S., Cheptou, P.-O., Petit, C., Meerts, P., Poncelet, M., Vekemans, X., et al. (2003). Genetic structure and mating systems of metaalicolous and nonmetallicolous populations of Thlaspi caerulescens New Phytol. 157, 633-641. doi: 10.1046/j.1469-8137.2003.00684.x

Dvořáková, M. (2003). Thlaspi L. Kvìtina Eeské Republiky 3, 171-179.

Elven, R., and Murray, D. F. (2008). New combinations in the Panarctic vascular plant flora. J. Bot. Res. Inst. Texas 2, 433-446.

Franzke, A., Lysak, M., Al-Shehbaz, I. A., Koch, M. A., and Mummenhoff, K. (2010). Cabbage family affairs: the evolutionary history of Brassicaceae. Trends Plant Sci. 16, 108-116. doi: 10.1016/j.tplants.2010.11.005

German, D. A. (2002). On the genus Thellungiella (Cruciferae). Turczaninowia 5, 2, 32-41 (in Russian).

German, D. A. (2006). Additions to Cruciferae of the flora of Kazakhstan. Bot. Zhurn. (St. Petersburg) 91(8), 1198-1211 (in Russian).

German, D. A. (2008). The genus Thellungiella (Cruciferae) in
Europe. Bot. Zhurn. (St. Petersburg) 93, 1273-1280 (in Russian).

German, D. A., and Al-Shehbaz, I. A. (2010). Nomenclatural novelties in miscellaneous Asian Brassicaceae (Cruciferae) Nordic J. Bot. 28, 646-651. doi: 10.1111/j.1756-1051.2010.00983.x

German, D. A., and Chen, W.-L. (2009). Notes on the family Brassicaceae in China. J. Syst. Evol. 47, 202-219. doi: 10.1111/j.1759-6831.2009.00022.x

German, D. A., and Ebel, A. L. (2005). Generic placement of Arabidopsis rupicola (Cruciferae). Turczaninowia 8, 3, 5-12 (in Russian).

German, D. A., Friesen, N., Neuffer, B., Al-Shehbaz, I. A., and Hurka, H. (2009). Contribution to ITS phylogeny of the Brassicaceae, with a special reference to some Asian taxa. Plant Syst. Evol. 283, 33-56. doi: 10.1007/s00606-009-0213-5

Ghars, M. A., Richard, L., Lefebvre-De Vos, D., Leprince, A.-S., Parre, E., et al. (2012). Phospholipases C and $\mathrm{D}$ modulate proline accumulation in Thellungiella halophila/salsuginea differently according to the severity of salt or hyperosmotic stress. Plant Cell Physiol. 53, 183-192.

Goff, S. A., Ricke, D., Lan, T. H. Presting, G., Wang, R., Dunn, M., et al. (2002). A Draft Sequence of the Rice Genome (Oryza sativa L. ssp. japonica). Science 296, 92-100.

Guo, Y., Jia, W., Song, J., Wang, D. Chen, M., and Wang, B. (2012). Thellungilla halophila is more adaptive to salinity than Arabidopsis thaliana at stages of seed germination and seedling establishment. Acta Physiol. Plant 34, 1287-1294. doi: 10.1007/s11738-012-0925-y

Hedge, I. C. (1968). Arabidopsis. Flora Iranica 57, 328-334.

Heidel, A. J., Ramos-Onsins, S E., Wang, W.-K., Chiang, T.-Y., and Mitchell-Olds, T. (2010). Population history in Arabidopsis halleri using multilocus analysis. Mol. Ecol. 19, 3364-3379. doi: 10.1111/j.1365-294X.2010.04761.x

Holub, J. (1998). Reclassifications and new names in vascular plants 1 . Preslia (Praha) 70, 97-122.

Iljinska, A., Didukh, Y., Burda, R. and Korotschenko, I. (2007) Ecoflora of Ukraine. Vol. 5. Kyiv: Phytosociocentre Press (in Ukrainian).

Inan, G., Zhang, Q., Li, P. H., Wang, Z. L., Cao, Z. Y., Zhang, H., et al. (2004). Salt cress. A halophyte and cryophyte Arabidopsis relative model system and its applicability to molecular genetic analyses of growth and development of extremophiles. Plant Physiol. 135, 1718-1737. doi: 10.1104/pp.104. 041723

Jalas, J., Suominen, J., and Lampinen, R. (1996). Atlas Florae Europaeae. 11. Cruciferae (Ricotia to Raphanus). Helsinki: Helsinki University Printing House.

Kadota, Y. (2007). Arabidopsis umezawana (Brassicaceae), a new species from Mt. Rishirizan, Rishiri Island, Hokkaido, Northern Japan. J. Japan Bot. 82, 232-237.

Karl, R., and Koch, M. A. (2013). A world-wide perspective on crucifer speciation and evolution: phylogeny, biogeography and trait evolution in tribe Arabideae. Ann. Bot. doi: 10.1093/aob/mct165. (accepted).

Kashem, M. A., Singh, B. R., Kubota, H., Nagashima, R. S., Kitajima, N., Kondo, T., et al. (2007). Assessing the potential of Arabidopsis halleri ssp. gemmifera as a new cadmium hyperaccumulator grown in hydroponics. Can. J. Plant Sci. 87, 499-502. doi: 10.4141/CJPS06058

Kawagoe, T., and Kudoh, H. (2010). Escape from floral herbivory by early flowering in Arabidopsis halleri subsp. gemmifera. Oecologia 164, 713-720. doi: 10.1007/s00442-010 1709-y

Koch, M., and Al-Shehbaz, I. A. (2004). Taxonomic and phylogenetic evaluation of the American "Thlaspi" species: identity and relationship to the Eurasian genus Noccaea (Brassicaceae). Syst. Bot. 29, 375-384. doi: 10.1600/036364404774195566

Koch, M., Bishop, J., and MitchellOlds, T. (1999). Molecular systematics and evolution of Arabidopsis and Arabis. Plant Biol. 1, 529-537. doi: 10.1111/j.14388677.1999.tb00779.x

Koch, M., Haubold, B., and MitchellOlds, T. (2000). Comparative evolutionary analysis of chalcone synthase and alcohol dehydrogenase loci in Arabidopsis, Arabis and related genera. Mol. Biol. Evol. 17 1483-1498. doi: 10.1093/oxfordjournals.molbev.a026248

Koch, M., Haubold, B., and MitchellOlds, T. (2001). Molecular systematics of the cruciferae: Evidence from coding plastome mat $\mathrm{K}$ and nuclear CHS sequences. Am. J. Bot. 88, 534-544. doi: 10.2307/2657117

Koch, M., and Mummenhoff, K. (2001). Thlaspi s. str. (Brassicaceae) versus Thlaspi s. l.: morphological and taxonomical characters in the light of ITS nrDNA sequence data. Plant Syst. Evol. 227, 209-225. doi: 10.1007/s006060170049 
Koch, M., Mummenhoff, K., and Al-Shehbaz, I. A. (2003). Molecular systematics, evolution, and population biology in the mustard family (Brassicaceae): a review of a decade of studies. Ann. Missouri Bot. Garden 90, 151-171. doi: $10.2307 / 3298580$

Koch, M., Mummenhoff, K., and Hurka, H. (1998). Systematics and evolutionary history of heavy metal tolerant Thlaspi caerulescens in Western Europe: evidence from genetic studies based on isozyme analysis. Biochem. Syst. Ecol. 26, 823-838. doi: 10.1016/S0305-1978(98)00057-X

Koch, M., Mummenhoff, K., and Zunk, K. (1993). Isoelektrische Fokussierung der Untereinheiten der Rubisco in Thlaspi (Brassicaceae): Weitere Hinweise auf eine Formengattung. Feddes Repert. 104, 371-381. doi: 10.1002/fedr.19931040513

Koch, M. A., and Al-Shehbaz, I. A. (2009). "Molecluar systematics and evolution of "wild" crucifers (Brassicaceae or Cruciferae)," in Biology and Breeding of Crucifers, ed S. Gupta (Boca Raton, FL: Taylor and Francis Group), 1-18. doi: 10.1201/9781420086096.ch1

Koch, M. A., Kiefer, M., German, D., Al-Shehbaz, I. A., Franzke, A., Mummenhoff, K., et al. (2012). BrassiBase: tools and biological resources to study characters and traits in the Brassicaceae - version 1.1. Taxon 61, 1001-1009.

Koch, M. A., and Matschinger, M. (2007). Evolution and genetic differentiation among relatives of Arabidopsis thaliana. Proc. Natl. Acad. Sci. U.S.A. 104, 6272-6277. doi: 10.1073/pnas.0701338104

Koch, M. A., Wernisch, M., and Schmickl, R. (2008). Arabidopsis thaliana's wild relatives: an updated overview on systematics, taxonomy and evolution. Taxon 57, 933-943.

Kolník, M., and Marhold, K. (2006). Distribution, chromosome numbers and nomenclature conspect of Arabidopsis halleri (Brassicaceae) in the Carpathians. Biologia (Bratislava) 61, 41-50. doi: 10.2478/s11756-006-0007-y

Krämer, U. (2010). Metal hyperaccumulation in plants. Annu. Rev. Plant Biol. 61, 517-534. doi: 10.1146/annurev-arplant-042809112156

Kubota, H. and Takenaka, C. (2003). Arabis gemmifera is a hyperaccumulator of $\mathrm{Cd}$ and $\mathrm{Zn}$. Int. J. Phytoremediat. 5, 197-201. doi: $10.1080 / 713779219$
Lamdan, N. L., Attia, Z., Moran, N., and Moshelion, M. (2012). The Arabidopsis-related halophyte Thellungiella halophila: boron tolerance via boron complexation with metabolites? Plant Cell Environ. 35, 735-746. doi: 10.1111/j.13653040.2011.02447.x

Lee, Y. P., Babakov, A. V., de Boer, B., Zuther, E., and Hincha, D. K. (2012). Comparison of freezing tolerance, compatible solutes and polyamines in geographically diverse collections of Thellungiella sp. and Arabidopsis thaliana accessions. BMC Plant Biol. 12:131. doi: 10.1186/1471-2229-12-131

Linnaeus, C. (1753). Species plantarum: exhibentes plantas rite cognitas, ad genera relatas, cum differentiis specificis, nominibus trivialibus, synonymis selectis, locis natalibus, secundum systema sexuale digestas. T. 2. Stockholm: Impensis Laurentii Salvii.

Llaurens, V., Castric, V., Austerlitz, F., and Vekemans, X. (2008) High paternal diversity in the self-incompatible herb Arabidopsis halleri despite clonal reproduction and spatially restricted pollen dispersal. Mol. Ecol. 17, 1577-1588. doi: $\quad$ 10.1111/j.1365-294X.2007. 03683.x

Lugan, R., Niogret, M. F., Leport, L., Guégan, J. P., Larher, F. R., Savouré, A., et al. (2010). Metabolome and water homeostasis analysis of Thellungiella salsuginea suggests that dehydration tolerance is a key response to osmotic stress in this halophyte. Plant J. 64, 215-229. doi: 10.1111/j.1365-313X. 2010.04323.x

Macnair, M. (2007). Life history variation in Thlaspi caerulescens. New Phytol. 173, 6-8. doi: 10.1111/j.1469-8137.2006.01948.x

Marhold, K. (2011). Brassicaceae. In: Euro+Med Plantbase - the information resource for EuroMediterranean plant diversity, 2006-2011). http://ww2.bgbm.org/ EuroPlusMed/

Marhold, K., Perný, M., and Kolník, M. (2003). Miscellaneous validations in Cruciferae and Crassulaceae. Willdenowia 33 69-70.

Meyer, C.-L., and Verbruggen, N. (2012). The use of the model species Arabidopsis halleri towards phytoextraction of cadmium polluted soils. N. Biotechnol. 30, 9-14. doi: 10.1016/j.nbt.2012.07.009

Meyer, C.-L., Vitalis, R., SaumitouLaprade, P., and Castric, V. (2009). Genomic pattern of adaptive divergence in Arabidopsis halleri, a model species for tolerance to heavy metal. Mol. Ecol. 18, 2050-2062. doi 10.1111/j.1365-294X.2009.04159.x

Meyer, F. K. (1973). Conspectus der "Thlaspi"-Arten Europas, Afrikas und Vorderasiens. Feddes Repert. 84, 449-470. doi 10.1002/fedr.19730840503

Meyer, F. K. (1979). Kritische Revision der "Thlaspi"Arten Europas, Afrikas und Vorderasiens, I. Geschichte, Morphologie und Chorologie. Feddes Repert. 90, 129-154. doi 10.1002/fedr. 19790900302

Meyer, F. K. (2006). Kritische Revision der "Thlaspi"-Arten Europas, Afrikas und Vorderasiens. Spezieller Teil. IX. Noccaea Moench. Haussknechtia 12, 1-343.

Milner, M. J., and Kochian, L. V. (2008). Investigating heavymetal hyperaccumulation using Thlaspi caerulescens as a model system. Ann. Bot. 102, 3-13. doi: 10.1093/aob/mcn063

Moench, C. (1802). Supplementum ad Methodum plantas a staminum site describendi. Marburgi Cattorum: In Officina Nova Libraria Academiae.

Mummenhoff, K., Franzke, A., and Koch, M. (1997a). Molecular data reveal convergence in fruit characters, traditionally used in the classification of Thlaspi s.l (Brassicaceae) - Evidence from ITS-DNA sequences. Bot. J. Linn. Soc. 125, 183-199.

Mummenhoff, K., Franzke, A., and Koch, M. (1997b). Molecular phylogenetics of Thlaspi s.l. (Brassicaceae) based on chloroplast DNA restriction site variation and sequences of the internal transcribed spacer of nuclear ribosomal DNA. Can. J. Bot 75, 469-482. doi: 10.1139/b97-051

Mummenhoff, K., and Koch, M. (1994). Chloroplast DNA restriction site variation and phylogenetic relationships in the genus Thlasp sensu lato (Brassicaceae). Syst. Bot. 19, 73-88. doi: 10.2307/2419713

Oh, D.-H., Dassanayake, M., Haas, J. S., Kropornika, A., Wright, C., d'Urzo, M. P., et al. (2010) Genome structures and halophytespecific gene expression of the extremophile Thellungiella parvula in comparison with Thellungiella salsuginea (Thellungiella halophila) and Arabidopsis. Plant Physiol. 154 1040-1052.

O'Kane, S. L. Jr., and Al-Shehbaz, I. A. (1997). A synopsis of Arabidopsis (Brassicaceae). Novon 7, 323-327.

O'Kane, S. L. Jr., and Al-Shehbaz, I. A. (2003). Phylogenetic position and generic limits of Arabidopsis (Brassicaceae) based on sequences of nuclear ribosomal DNA. Ann. Missouri Bot. Gard. 90, 603-612.

Orsini, F., d'Urzo, M. P., Inan, G., Serra, S., Oh, D.-H., Mickelbart, M. V., et al. (2010). A comparative study of salt tolerance parameters in 11 wild relatives of Arabidopsis thaliana. J. Exp. Bot. 61, 3787-3798.

Pang, Q., Guo, J., Chen, S., Chen, Y., Zhang, L., Fei, M., et al. (2012). Effect of salt treatment on the glucosinolate-myrosinase system in Thellungiella salsuginea. Plant Soil 355, 363-374. doi: 10.1007/s11104011-1108-0

Paterson, D. J., Cooper, J., Kirk, P. M., Pyle, R. L., and Remsen, D. P. (2010). Names are key to the big new biology. Trends Evol. Ecol. 25, 696-689. doi: 10.1016/j.tree.2010.09.004

Pauwels, M., Saimitou-Laprade, P. Holl. A. C., Petit, D., and Bonin, I. (2005). Multiple origin of metallicolous populations of the pseudometallphyte Arabidopsis halleri (Brassicaceae) in central Europe: the cpDNA testimony. Mol. Ecol. 14, 4403-4414. doi: 10.1111/j.1365-294X.2005.02739.x

Pauwels, M., Vekemans, X., Godé, C., Frérot, H., Castric, V., and Saimitou-Laprade, P. (2012). Nuclear and chloroplast DNA phylogeography reveals vicariance among European populations of the model species for the study of metal tolerance, Arabidopsis halleri (Brassicaceae). New Phytol. 193, 916-928. doi: 10.1111/j.1469-8137.2011.04003.x

Pujados Salvá, A. (1993). "Thlaspi L," in Flora Iberica: plantas vasculares de la Península Ibérica e Islas Baleares, eds S. Castroviejo, C. Aedo, C. Gómez Campo, M. Laínz, P. Montserrat, R. Morales, et al. (Madrid: Real Jardín Botánico, C.S.I.C.), 255-264.

Reeves, R. D. (1988). Nickel and zinc accumulation by species of Thlaspi L., Cochlearia L., and other genera of the Brassicaceae. Taxon 37, 309-318 doi: $10.2307 / 1222140$

Reeves, R. D., and Baker, A. J. M. (2000). "Metal-accumulating plants", in Phytoremediation of Toxic Metals-Using Plants to Clean Up the Environment, eds I. Raskin and B. D. Ensley (New York, NY: Wiley), 193-229.

Reeves, R. D., and Brooks, R. R. (1983). European species of Thlaspi L. (Cruciferae) as indicators of nickel and zinc. J. Geoch. Explor. 18, 275-283. doi: 10.1016/03756742(83)90073-0

Reeves, R. D., Kruckeberg, A. R. Adigüzel, N., and Krämer, U. (2001). Studies on the flora of 
serpentine and other metalliferous areas of western Turkey. S Afr. J. Sci. 97, 513-517.

Roux, C., Castric, V., Pauwels, M., Wright, S. I., Saimitou-Laprade, P., and Vekemans, X. (2011). Does speciation between Arabidopsis halleri and Arabidopsis lyrata coincide with major changes in a molecular target of adaptation? PLoS ONE 6:e26872. doi: 10.1371/journal.pone.0026872

Schmickl, R., and Koch, M. A. (2011). Arabidopsis hybrid speciation processes. Proc. Natl. Acad. Sci. U.S.A. 108, 14192-14197. doi: 10.1073/pnas.1104212108

Shimizu, K. K., Fujii, S. H., Marhold, K., Watanabe, K., and Kudoh, H. (2005). Arabidopsis kamchatica (Firsh. ex DC.) K. Shimizu \& Kudoh and A. kamchatica subsp. kawasakiana (Makino) K. Shimizu \& Kudoh, new kombinations. Acta Phytotax. Geobot. 156, 163-172.

Shimizu, K. K., Kudoh, H., and Kobayashi, M. J. (2011). Plant sexual reproduction during climate change: gene function in natura studied by ecological and evolutionary systems biology. Ann. Bot. 108, 777-787. doi: 10.1093/aob/mcr180

Taylor, S. I., and Macnair, M. R. (2006). Within and between variation for zinc and nickel accumulation in two species of Thlaspi (Brassicaceae). New Phytol. 169, 505-513. doi: 10.1111/j.1469-8137.2005.01625.x

Thellungiella halophila Genome Project. (2011). http://www. phytozome.net/thellungiella/ thellungiella/. Accessed online at 10th June 2013

The Plant List. (2010). Version 1. Published on the Internet. http://www.theplantlist.org/. Accessed online at 1st April 2013.

Turner, T. L., Bourne, E. C., Von Wettberg, E. J., Hu, T. T., and Nuzhdin, S. V. (2010). Population resequencing reveals local adaptation of Arabidopsis lyrata to serpentine soils. Nat. Genet. 42, 260-263. doi: 10.1038/ng.515

Turner, T. L., von Wettberg, E. J., and Nuzhdin, S. V. (2008). Genomic analysis of differentiation between soil types reveals cadidate genes for local adaptation in Arabidopsis lyrata. PLoS ONE 3:e3183. doi: 10.1371/journal.pone. 0003183

Van Rossum, F., Bonnin, I. Fénart, S., Pauwels, M., Petit, D., and Suamitou-Laprade, P. (2004). Spatial genetic structure within a metallicolous population of Arabidopsis halleri, a clonal, selfincompatible and heavy-metal tolerant species. Mol. Ecol. 13, 2959-2967. doi: 10.1111/j.1365294X.2004.02314.x

Vogel-Mikus, K., Drobne, D., and Regvar, M. (2005). Zn, Cd and $\mathrm{Pb}$ accumulation and arbuscular mycorrhizal colonisation of pennycress Thlaspi praecox Wulf. (Brassicaceae) from the vicinity of a lead mine and smelter in Slovenia.
Environ. Pollut. 133, 233-242. doi 10.1016/j.envpol.2004.06.021

Warwick, S. I., Al-Shehbaz, I. A., and Sauder, C. I. (2006). Phylogenetic position of Arabis arenicola and generic limits of Aphragmus and Eutrema (Brassicaceae) based on sequences of nuclear ribosomal DNA. Can. J. Bot. 84, 269-281. doi: 10.1139/b05-161

Wu, H.-J., Zhang, Z. G., Wang, J.-Y., Oh, D.-H., Dassanayake, M., Liu, B. G., et al. (2012). Insights into salt tolerance from the genome of Thellungiella salsuginea. Proc. Natl. Acad. Sci. U.S.A. 109, 12219-12224.

Yang, R., Jarvis, D. E., Chen, H., Beilstein, M. A., Grimwood, J., Jenkins, J., et al. (2013) The reference genome of the halophytic plant Eutrema salsugineum. Front. Plant Sci. 4:46. doi: 10.3389/fpls.2013.00046

$\mathrm{Yu}, \mathrm{J}$., Hu, S., Wang, J., Wong, G. K., Li, S., Liu, B., et al. (2002). A draft sequence of the rice genome (Oryza sativa L. ssp. indica). Science 296, 79-92. doi: 10.1126/science. 1068037

Zhou, T.-Y., Lu, L.-L., Yang, G., and AlShehbaz, I. A. (2001). "Brassicaceae (Cruciferae)," in Flora of China, 8 (Brassicaceae throgh Saxifragaceae), eds Z.-G. Wu and P. H. Raven (Beijing: Science Press; St. Louis: Missouri Botanical Garden Press) 1-193.

Zunk, K., Mummenhoff, K., Koch, M. and Hurka, H. (1996). Phylogenetic relationships of Thlaspi s.l. (subtribe Thlaspidinae, Lepidieae) and allied genera based on chloroplast DNA restriction site variation. Theor. Appl. Genet 92, 375-381. doi: 10.1007/BF00223682

Conflict of Interest Statement: The authors declare that the research was conducted in the absence of any commercial or financial relationships that could be construed as a potential conflict of interest.

Received: 26 April 2013; accepted: 02 July 2013; published online: 31 July 2013

Citation: Koch MA and German DA (2013) Taxonomy and systematics are key to biological information: Arabidopsis, Eutrema (Thellungiella), Noccaea and Schrenkiella (Brassicaceae) as examples. Front. Plant Sci. 4:267. doi: 10.3389/fpls.2013.00267

This article was submitted to Frontiers in Plant Physiology, a specialty of Frontiers in Plant Science.

Copyright (c) 2013 Koch and German. This is an open-access article distributed under the terms of the Creative Commons Attribution License (CC BY). The use, distribution or reproduction in other forums is permitted, provided the original author(s) or licensor are credited and that the original publication in this journal is cited, in accordance with accepted academic practice. No use, distribution or reproduction is permitted which does not comply with these terms. 